\title{
Penambahan Variasi Kompos Dapur Terhadap Germination Indeks Tanah
}

\author{
Sri Slamet Mulyati", Pujiono, Teguh Budi Prijanto, Elanda Fikri \\ Jurusan Kesehatan Lingkungan Poltekkes Kemenkes RI Bandung, Jalan Babakan Loa No.10A, Gunung Batu, Cimahi Utara. \\ Kota Cimahi 40514, Indonesia \\ *Corresponding author: srislamet@staff.poltekkesbandung.ac.id
}

Info Artikel:Diterima 9 Januari 2022 ; Direvisi 29 Januari 2022 ; Disetujui 1 Februari 2022

Tersedia online : 19 Februari 2022 ; Diterbitkan secara teratur : Februari 2022

Cara sitasi (Vancouver): Mulyati SS, Pujiono P, Prijanto TB, Fikri E. Penambahan Variasi Kompos Dapur Terhadap Germination Indeks Tanah. Jurnal Kesehatan Lingkungan Indonesia [Online]. 2022 Feb;21(1):99-105. https://doi.org/10.14710/jkli.21.1.99-105.

\begin{abstract}
ABSTRAK
Latar Belakang: Kompos berkualitas bagus dapat dilihat dari tingkat kematangan dan stabilitas kompos itu sendiri.Germination Index (GI) merupakan uji fitotoksisitas kompos terbaik karena alasan kemudahan dan keandalan. Nilai Germination Index (GI) akan mengalami penurunan ketika kondisi tanaman tercemar oleh logam berat.

Metode: Penelitian ini adalah eksperime semu, skala laboratorium. Tujuan penelitian ini adalah untuk mengetahui nilai Germination Index (GI) pada berbagai kondisi tanah. Benih yang ditanam di berbagai media adalah kacang hijau atau Vigna radiata. Variabel yang diamati dalam penelitian ini adalah Germination Index. Germination Index merupakan nilai perkalian persentase perkecambahan (Seed Germination) dan Panjang Akar (Root Length). Variabel penting lain yang diamati adalah $\mathrm{pH}$ tanah dan logam berat biji kacang hijau.

Hasil: Hasil penelitian menunjukkan bahwa nilai persentase perkecambahan (SG) campuran tanah kompos adalah 80-86,67\%. Panjang Akar (RL) pada campuran tanah kompos adalah 0,7-1,36 cm. Nilai Germination Index (GI) campuran tanah kompos sebesar 17,46-34,89\%. Tidak ada perbedaan yang signifikan dalam nilai Germination Index (GI) antara campuran tanah kompos yang berbeda-beda (1: 1, 2: 1.3: 1).

Simpulan: Nilai Germination Index tanah yang terkontaminasi Chrom lebih besar dari campuran tanah kompos. Semakin tinggi nilai pH kompos semakin menurun nilai panjang akar sehingga memengaruhi nilai Germination Index menjadi lebih rendah dibandingkan pertumbuhan benih pada media tanah terkontaminasi Chrom.
\end{abstract}

Kata kunci: kontaminan tanah; kualitas kompos

\section{ABSTRACT:}

Title: Adding Variations In Kitchen Compost To Soil Index Germination

Background: Good quality compost can be seen from the level of maturity and stability of the compost itself.. Germination Index (GI) the best compost phytotoxicity test for reasons of ease and reliability. The Germination Index (GI) value will decrease when plant conditions are contaminated by metals.

Method: Th study was a quasi-experimental, laboratory scale. The purpose of this study was to determine the value of the Germination Index (GI) in various soil conditions Seeds planted on various media are Vigna radiata. The variable observed in th study the Germination Index. Germination index value the multiplication of the percentage of Seed Germination (SG) and Root Elongation (RE).Other important variables observed were soil $\mathrm{pH}$ and heavy metals in Vigna radiata seeds.

Result: The results showed that the value of Seed Germination $(S G)$ in the soil added by compost variation was 80-86.67\%. The value of Root Length (RL) on the soil added with compost variation $0.7-1.36 \mathrm{~cm}$. Germination 
Index (GI) value in the soil added by compost variation 17.46-34.89\%. There was no significant difference in Germination Index (GI) values between different soil conditions with the addition of compost (1:1,1:2.1:3) Conclusion: The Germination Index value of soil contaminated with Chromium was greater than that of the compost soil mixture. The higher the $\mathrm{pH}$ value of the compost, the lower the root length value so that the Germination Index value was lower than the growth of seeds on soil contaminated with Chromium.

Keywords: Soil contamination; compost quality

\section{PENDAHULUAN}

Kualitas kompos yang harus diperhatikan sebelum diaplikasikan ke media tanah diantaranya adalah stabilitas dan tingkat kematangan kompos itu sendiri. ${ }^{1,2}$ Kompos yang belum stabil dan matang akan berdampak buruk pada proses perkecambahan, pertumbuhan tanaman, dan terhadap tanah itu sendiri. Stabilitas kompos erat kaitannya dengan ketahanan bahan-bahan organik untuk tetap tersedia dalam kompos sebagai sumber energi mikroba dalam menguraikan sampah. Adapun tingkat kematangan kompos erat kaitannya dengan pertumbuhan tanaman. ${ }^{3,4}$ Fitotoksisitas merupakan cara terbaik untuk melakukan evaluasi terkait perkecambahan dan pertumbuhan. ${ }^{5,6}$

Germination Index (GI) merupakan cara uji fitotoksisitas kompos yang terbaik karena alasan kemudahan dan terpercaya. Germination Index (GI) ini merupakan kombinasi pengukuran nilai relative perkecambahan dan pertambahan panjang akar kecambah. Hasil yang didapat akan mengindikasikan toksisitas kompos yang diuji. Nilai $80 \%$ GI mengindikasikan bahwa tanaman terbebas dari zat-zat toksik dan kompos sudah dalam kondisi matang.

Chrom merupakan salah satu unsur logam berat, menempati urutan ke tujuh sebagai polutan di muka bumi ini. Tingginya konsentrasi Chrom pada sebuah penelitian sebelumnya menunjukkan adanya gangguan pada kehidupan tanaman, berkurangnya unsur protein, terhambatnya aktivitas enzim, klorosis dan nekrosis pada tanaman. ${ }^{7}$ Sebuah penelitian menunjukkan bahwa kompos "Bio Waste" mengandung logam berat Chrom sebesar $61 \mathrm{mg} / \mathrm{Kg}$ kompos. ${ }^{8}$ Sementara ada penelitian lain menunjukkan bahwa setiap penambahan Chrom $(5-100 \mathrm{mg} / \mathrm{Kg})$ pada sampel tanaman Hibiscus esculentus menurunkan Germination Index (GI) artinya tanaman mengalami penurunan daya toleransinya terhadap zat toksik sehingga proses perkecambahan terhambat. ${ }^{9}$ Rasio sampah kering dan basah yang berbeda dalam penelitian lainnya menunjukkan Germination Index (GI) yang berbeda juga. Rasio 1:9 menghsilkan nilai Germination Index (GI) yang paling tinggi yaitu $97,3 \%{ }^{10}$ Atas dasar tersebut penelitian ini bertujuan untuk mengetahui nilai Germination Indeks (GI) pada berbagai kondisi tanah.

\section{MATERI DAN METODE}

Jenis penelitian yang digunakan adalah kuasi eksperimen dengan desain static group comparison. Objek dalam penelitian ini adalah tanah tidak tercemar yang diambil dari halaman. Variabel penelitian adalah sebagian tanah tidak tercemar (sebagai kontrol), tanah yang diberi perlakuan khusus dengan penambahan variasi kompos, larutan Chrom, campuran tanah dan kompos ditambah larutan Chrom.

Langkah pertama yang dilakukan dalam penelitian ini adalah membuat bioaktivator mol nasi dengan perbandingan nasi basi dan gula 1:1, penambahan air $500 \mathrm{ml}$, diamkan selama 5-7 hari sampai tercium bau tape. Langkah kedua melakukan pengomposan dengan perbandingan green biomass dan sawddust 9:1. Langkah ketiga menyiapkan stok larutan Chromium dengan cara menimbang 2,28 gram potassium dichromat, menambahkan $1000 \mathrm{ml}$ aquadest, homogenkan. Langkah keempat menyiapkan tanah dengan campuran kompos sebanyak 3 variasi rasio $(1: 1,1: 2,1: 3)^{11}$ Langkah kelima menyiapkan tanah terkontaminasi Chrom (rasio 10:1) dengan cara menimbang 100 gram tanah, menambahkan 10 gram larutan standar Chrom.

Campurkan keduanya dengan merata dan biarkan selama 2 minggu untuk proses stabilisasi Chrom. Langkah keenam menyiapkan tanah terkontaminasi Chrom dengan penambahan kompos (2:1). Caranya timbang 100 gram tanah, tambahkan 10 gram larutan standar Chrom, Tambahkan kompos sebanyak 50 gram, kemudian campurkan keduanya dengan merata. Langkah ketujuh menyiapkan tanah tidak tercemar sebanyak $2 \mathrm{Kg}$, diambil dari halaman. Langkah kedelapan menyiapkan kompos sebanyak $2 \mathrm{Kg}$. Langkah kesembilan menyiapkan sampel pengamatan yakni masukkan 20 biji kacang hijau ke setiap cawan petri yang sudah berisi sampel tanah, tutup rapat dengan menggunakan plastic foil, inkubasi di tempat gelap selama 72 jam dalam suhu ruang. ${ }^{12}$. Amati perkecambahan benih kacang hijau dengan indikator Germination Index (GI).

\section{HASIL DAN PEMBAHASAN}

Nilai Seed Germination (SG), Root Length (RL), dan Germination Index (GI) biji kacang hijau dapat dilihat pada tabel 1 .

Persentase pertumbuhan (SG) biji kacang hijau pada berbagai kondisi tanah berada pada kisaran 80100\%. Pertambahan panjang akar (RL) biji kacang hijau pada berbagai kondisi tanah berada pada kisaran $0,7-5,2 \mathrm{~cm}$. Nilai Germination Indeks (GI) berada pada kisaran 10,32-161,24\%.

Nilai $\mathrm{pH}$ pada berbagai kondisi tanah dan keberadaan logam berat secara kualitatif pada kecambah biji kacang hijau dapat dilihat pada tabel 2 . 
Tabel 1. Nilai Seed Germination (SG), Root Length (RL), dan Germination Index (GI) Biji Kacang Hijau pada Berbagai Kondisi Tanah

\begin{tabular}{|c|c|c|c|}
\hline Perlakuan & $\begin{array}{c}\text { Nilai } \\
\text { Seed Germination } \\
\text { (SG) } \%\end{array}$ & $\begin{array}{c}\text { Nilai } \\
\text { Root Length (RL) } \\
\text { Cm }\end{array}$ & $\begin{array}{l}\text { Nilai } \\
\text { Germination Index } \\
\text { (GI) } \%\end{array}$ \\
\hline \multicolumn{4}{|l|}{ Tanah + Crom 1:10 } \\
\hline Pengulangan Pertama & 85 & 4,38 & 71,61 \\
\hline Pengulangan Kedua & 100 & 3,70 & 112,29 \\
\hline Pengulangan Ketiga & 90 & 3,47 & 161,24 \\
\hline Rata-rata & 91,67 & 3,85 & 115,05 \\
\hline \multicolumn{4}{|l|}{ Kompos + Tanah 2:1 } \\
\hline Pengulangan Pertama & 80 & 1,31 & 20,12 \\
\hline Pengulangan Kedua & 90 & 1,52 & 41,43 \\
\hline Pengulangan Ketiga & 70 & 0,93 & 33,59 \\
\hline Rata-rata & 80 & 1,25 & 31,71 \\
\hline \multicolumn{4}{|l|}{ Tanah Tercemar + Kompos 2:1 } \\
\hline Pengulangan Pertama & 100 & 3,00 & 57,75 \\
\hline Pengulangan Kedua & 100 & 1,71 & 51,75 \\
\hline Pengulangan Ketiga & 100 & 1,62 & 83,46 \\
\hline Rata-rata & 100 & 2,11 & 64,32 \\
\hline \multicolumn{4}{|l|}{ Kompos + Tanah 1:1 } \\
\hline Pengulangan Pertama & 100 & 1,72 & 33,01 \\
\hline Pengulangan Kedua & 95 & 1,59 & 45,83 \\
\hline Pengulangan Ketiga & 65 & 0,77 & 25,84 \\
\hline Rata-rata & 86,67 & 1,36 & 34,89 \\
\hline \multicolumn{4}{|l|}{$\begin{array}{l}\text { Tanah Tidak Tercemar } \\
\text { (Kontrol) }\end{array}$} \\
\hline Pengulangan Pertama & 100 & 5,20 & Kontrol \\
\hline Pengulangan Kedua & 85 & 3,88 & Kontrol \\
\hline Pengulangan Ketiga & 65 & 2,98 & Kontrol \\
\hline Rata-rata & 83,33 & 4,02 & Kontrol \\
\hline \multicolumn{4}{|l|}{ Kompos + Tanah 3:1 } \\
\hline Pengulangan Pertama & 95 & 1,04 & 19,06 \\
\hline Pengulangan Kedua & 75 & 0,45 & 10,32 \\
\hline Pengulangan Ketiga & 75 & 0,59 & 23,00 \\
\hline Rata-rata & 81,67 & 0,70 & 17,46 \\
\hline
\end{tabular}

Tabel 2. Nilai pH dan Logam Berat Pada Kecambah Kacang Hijau

\begin{tabular}{lcc}
\multicolumn{1}{c}{ Perlakuan } & Nilai pH & $\begin{array}{c}\text { Logam berat pada } \\
\text { kecambah }\end{array}$ \\
\hline Tanah + Crom 1:10 & 7,2 & Negatif \\
Kompos + Tanah 2:1 & 8,1 & Negatif \\
Tanah Tercemar + Kompos 2:1 & 7,2 & Negatif \\
Kompos + Tanah 1:1 & 8,1 & Negatif \\
Tanah Tidak Tercemar (Kontrol) & 6,3 & Negatif \\
Kompos + Tanah 3:1 & 8,2 & Negatif \\
\hline
\end{tabular}

Nilai $\mathrm{pH}$ pada berbagai kondisi tanah berkisar antara 6,3-8,2. $\mathrm{pH}$ pada seluruh perlakuan cenderung basa (>7), sedangkan kandungan logam berat pada kecambah secara keseluruhan adalah negatif.

Data nilai Germination Index berdistribusi normal sehingga dilakukan uji Anova. Hasil uji statistik (tabel 3) menunjukkan bahwa tidak ada perbedaan rata-rata yang bermakna dalam hal
Germination Index antara variasi berat kompos rasio 1:1, rasio 2:1, dan rasio 3:1 ( $p$ value $>0,05$ ).

Ketika didapat nilai GI tanah tercemar lebih tinggi daripada tanah yang ditambahkan kompos, uji statistik dilanjutkan untuk mengetahui fenomena apa yang terjadi pada kasus tersebut. Uji korelasi dilakukan untuk mendapatkan trend korelasi panjang akar dikaitkan dengan $\mathrm{pH}$ tanah. Hasil uji dapat dilihat pada tabel 4 . 
Tabel 3. Uji Beda Germination Index (GI) Antar Variasi Kondisi Tanah

\begin{tabular}{lcc}
\multicolumn{1}{c}{ Perlakuan } & $\begin{array}{c}\text { Nilai } \\
\text { Rata-rata } \\
\text { Germination Index } \\
\text { (GI) } \%\end{array}$ & $\begin{array}{c}\text { Nilai } \\
\text { P Value }\end{array}$ \\
\hline Kompos + Tanah 1:1 & 34.89 & \\
Kompos + Tanah 2:1 & 31.71 & $>0,05$ \\
Kompos + Tanah 3:1 & 17.46 & $<0,05$ \\
\hline $\begin{array}{l}\text { Tanah Tercemar dengan setiap } \\
\text { variasi kompos }\end{array}$ & 161,24 & $>0,05$ \\
$\begin{array}{l}\text { Tanah Tercemar + kompos dengan } \\
\text { setiap variasi kompos }\end{array}$ & 83,46 & \\
\hline
\end{tabular}

Tabel 4. Uji Korelasi Antara pH dan Panjang Akar (RL)

\begin{tabular}{lccc}
\hline \multicolumn{1}{c}{ Perlakuan } & Nilai Rata-rata & Nilai r & $\begin{array}{c}\text { Nilai } \\
P \text { Value }\end{array}$ \\
\hline $\mathrm{pH}$ & 7,52 & & \\
Panjang akar (RL) & 2,21 & $-0,835$ & 0,000 \\
\hline
\end{tabular}

Ada hubungan yang bermakna antara $\mathrm{pH}$ dan panjang akar pada setiap media tanah yang berbeda. Arah hubungan negatif artinya semakin besar nilai $\mathrm{pH}$ diikuti dengan penurunan panjang akar kecambah. Sebesar $83,5 \%$ variabel $\mathrm{pH}$ dapat memprediksi panjang akar biji kacang hijau yang tumbuh dalam berbagai media tanah tersebut.

Keberadaan logam berat Chrom telah memengaruhi tanah untuk melepaskan ion $\mathrm{H}^{+}$dan menghasilkan $\mathrm{OH}^{-}$yang meningkatkan $\mathrm{pH}$ tanah menjadi 7,2, mendekati $\mathrm{pH}$ netral. Kondisi ini juga dialami pada tanah tercemar logam berat yang sudah ditambahkan kompos. Proses yang terjadi pada peristiwa ini disebut sebagai hidrolisis, yaitu pecahnya molekul air $\left(\mathrm{H}_{2} \mathrm{O}\right)$ dan ion Natrium $\left(\mathrm{Na}^{+}\right)$ menghasilkan $\mathrm{OH}^{-}$yang meningkatkan $\mathrm{pH}$ tanah. Reaksi yang terjadi pada peristiwa hidrolisis digambarkan sebagai berikut : ${ }^{13}$

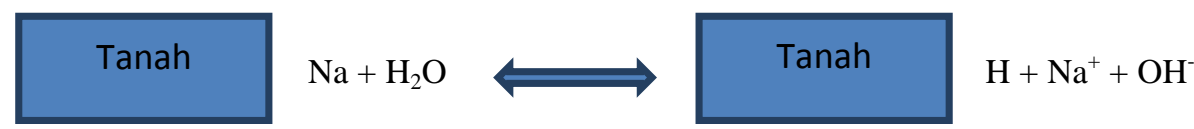

Gambar 1. Peristiwa hidrolisis pada tanah

Kondisi ini sejalan dengan penelitian yang dilakukan pada populasi Eringium caeruleum, diperoleh nilai germination index yang paling tinggi pada $\mathrm{pH} 7 .^{14}$ Faktor-faktor lingkungan yang diamati pada penelitian tersebut diantaranya adalah $\mathrm{pH}$, temperatur, kadar garam, dan proses inkubasinya (gelap/terang). Kondisi $\mathrm{pH}$ tinggi atau rendah konsentrasi $\mathrm{H}^{+}$, makronutrien tidak terlalu kuat ikatannya dengan permukaan tanah sehingga masih memungkinkan ketersediaan untuk serapan oleh tanaman, dan lebih banyak ketersediaannya dibandingkan pada kondisi $\mathrm{pH}$ rendah. ${ }^{15}$ Kondisi ini mendukung perkecambahan biji kacang hijau walaupun tanah terkontaminasi logam berat Chrom. ${ }^{16}$

Proses penyebab pengurangan konsentrasi kontaminan dalam larutan tanah karena kontak dengan partikel atau butir tanah dibagi menjadi proses adsortif dan proses non adsortif. Proses adsortif dalam penelitian ini tergambarkan dalam perlakuan tanah yang terkontaminasi Chrom namun biji kacang hijau tetap tumbuh optimal. Kondisi ini menggambarkan bahwa butiran tanah yang halus mempunyai permukaan yang luas sehingga reaksi yang terjadi adalah reaksi permukaan. Kontaminan Chrom hanya menempel pada permukaan tanah, tidak dalam bentuk terlarut sehingga tidak memengaruhi pertumbuhan biji kacang hijau.

Proses non adsortif terjadi ketika konsentrasi larutan Chrom sudah melebihi batas jenuh, zat tersebut akan terpresipitasi membentuk presipitat halus dan menempel pada permukaan partikel tanah. Proses non adsortif lainnya terjadi ketika kontaminan Chrom terjebak dalam ruang pori partikel tanah dan menempel pada butiran tanah tersebut saat proses redistribusi. Proses jebakan ini terjadi atau berhubungan dengan mobilitas atau transpor kontaminan Chrom dalam tanah. Proses chelation yaitu terikatnya kontaminan Chrom oleh asam organik seperti sitrat atau asam asetat dalam tanah, juga dapat mengurangi konsentrasi logam tersebut dalam larutan tanah sehingga menghilangkan logam yang beracun.

Dominannya reaksi permukaan tanah akibat permukaan yang luas, bentuk presipitat yang tidak mudah larut, dan proses chelation logam Chrom oleh 
asam organik yang secara alamiah merupakan unsurunsur yang ada dalam tanah., dapat memengaruhi berkurangnya konsentrasi Chrom dalam tanah sehingga biji kacang hijau masih bisa tumbuh optimal.

Sesungguhnya daya kecambah suatu benih dipengaruhi oleh mutu benih itu sendiri. Benih yang bermutu tinggi dicirikan oleh tingkat kemurnian tinggi, daya kecambah tinggi, vigor tinggi, dan bebas dari penyakit. Mutu benih menyangkut mutu genetis, fisik, fisiologis dan patologis. Mutu genetis menjabarkan sifat-sifat unggul yang diwariskan dari pohon induknya. Benih murni dapat diseleksi selama pengolahan benih, mutu fisik tidak hanya menyangkut struktur morfologis tetapi juga ukuran dan berat benih. Sementara mutu fisiologis berhubungan dengan viabilitas dan vigor. Mutu patologis menunjukkan kesehatan benih. $^{17}$

Biji kacang hijau yang ditanam pada tanah dengan berbagai perlakuan, tidak dilakukan seleksi benih secara detil seperti tersebut di atas. Peneliti hanya menyiapkan benih dari sumber yang sama, dan diperoleh pada waktu yang bersamaan pula. Nilai Germination Index (GI) yang tinggi pada tanah yang terkontaminasi Chrom menunjukkan bahwa sejak awal boleh jadi mutu benih kacang hijau tersebut bermutu tinggi, terutama untuk tolok ukur vigor benih. Vigor benih merupakan indikasi viabilitas benih yang menunjukkan benih kuat tumbuh di lapangan dalam kondisi yang suboptimum, dan tahan untuk disimpan dalam kondisi yang tidak ideal. ${ }^{18}$

Setiap tumbuhan mempunyai kemampuan untuk menyerap logam, namun dalam konsentrasi yang berbeda-beda. ${ }^{19}$ Kemampuan untuk menyerap logam dalam konsentrasi tinggi disebut sebagai hiperakumulator. Tanaman hiperakumulator mampu mengakumulasi logam dengan konsentrasi lebih dari 100 kali melebihi tanaman normal, ketika tanaman normal tersebut mengalami keracunan. ${ }^{20}$ Biji kacang hijau tumbuh pada tanah yang terkontaminasi logam berat Chrom, karena karakteristik tanahnya yang mampu mengadsorpsi kontaminan, benih kacang hijaunya bermutu tinggi, dan sifat hiperakumulator yang dimilikinya sehingga lebih toleran.

Kondisi ini sejalan dengan penelitian yang dilakukan pada berbagai benih tanaman Vigna radiata, Trigonella foenum, Oryza sativa, dan Pennisetum glaucum, didapat hasil efek toksik logam berat Cadmium terendah adalah pada benih Vigna radiata (biji kacang hijau). Biji kacang hijau pada kondisi terpapar kontaminan Cadmium 10 ppm ini mempunyai nilai Seed Germination (SG) $100 \%$ dan Root Length (RL) $5,2 \mathrm{~cm}^{21}$ Penelitian lain, juga menunjukkan nilai Seed Germination (SG) $100 \%$ dan Root Length $(R L) 6,59 \mathrm{~cm}$ pada kondisi biji kacang hijau terpapar logam berat Chrom 50 ppm. Kondisi ini, merupakan efek toksik terendah dibandingkan dengan biji tanaman lainnya pada paparan konsentrasi yang sama. ${ }^{22}$ Namun demikian penelitian lain menunjukkan bahwa nilai Germination Index (GI) tanaman Vigna radiata mengalami penurunan ketika dipaparkan kompos yang mengandung logam berat $\mathrm{Pb}^{23}$

Hasil uji statistik pada tabel 3 menunjukkan bahwa tidak ada perbedaan yang bermakna nilai Germination Index (GI) diantara berbabagi kondisi tanah dengan penambahan kompos 1:1, 2:1, dan 3:1 ( $p$ value $>0,05$ ). Sebagai data dukung penting lainnya, peneliti melakukan uji korelasi (tabel 4) antara $\mathrm{pH}$ dengan panjang akar, didapat hubungan yang bermakna dan menunjukkan korelasi yang negatif ( $p$ value 0,000 ). Semakin besar nilai $\mathrm{pH}$ diikuti dengan penurunan panjang akar kecambah. Pada saat $\mathrm{pH}$ cenderung basa, benih kacang hijau pada campuran tanah kompos dapat tumbuh namun mengalami penurunan panjang akar sehingga mempengaruhi nilai Germination Index menjadi lebih rendah dibandingkan dengan kecambah pada media lainnya.

Apabila dibandingkan dengan tanah yang terkontaminasi Chrom, nilai Seed Germination ( $S G)$ pada tanah dengan variasi berat kompos, lebih rendah $(<90 \%)$. Kondisi seperti ini, dalam teknologi benih disebut sebagai peristiwa dormansi benih. Dormansi benih adalah suatu keadaan berhenti tumbuh yang dialami organisme hidup atau bagiannya sebagai tanggapan atas suatu keadaan yang tidak mendukung pertumbuhan normal. Pemicu dormansi dapat bersifat mekanis, keadaan fisik lingkungan, atau kimiawi. Dormansi juga dapat didefinisikan sebagai suatu pertumbuhan dan metabolisme yang terpendam, dapat disebabkan oleh lingkungan yang tidak baik atau oleh faktor dari dalam tumbuhan itu sendiri. Seringkali jaringan yang dorman gagal tumbuh meskipun berada dalam kondisi yang ideal.

Biji kacang hijau yang ditanam pada tanah dengan variasi berat kompos mempunyai mutu benih lebih rendah dibandingkan mutu benih biji kacang hijau yang ditanam pada tanah yang terkontaminasi Chrom, apabila dilihat dari daya kecambahnya. Jumlah biji kacang hijau dorman yang ditanam pada tanah dengan variasi berat kompos, lebih banyak dibandingkan dengan jumlah biji kacang hijau yang ditanam pada tanah yang terkontaminasi Chrom. Faktor penyebab dormansi pada biji kacang hijau tersebut dapat disebabkan oleh embrio tidak berkembang, penyerapan air terganggu karena kulit biji yang impermeabel, dan bagian biji mengandung zat kimia penghambat. Media tanam dan komposisi hara yang tepat juga menentukan produksi dan ukuran umbi yang dihasilkan. Di satu sisi terhambatnya penyerapan air oleh tanaman dapat meningkatkan persentase perkecambahan apabila ke dalam media tanaman tersebut sengaja dipaparkan materialmaterial nutrisi yang sangat halus(nano material) yang dibutuhkan tanaman. ${ }^{24}$

Kondisi media tanah dan juga komposisi hara dalam penelitian ini, tidak diuji terlebih dahulu untuk setiap perlakuan, hanya peneliti mengambil media pada waktu ,tempat, dan kedalaman yang sama. Biji kacang hijau tumbuh pada tanah yang terkontaminasi logam berat Chrom, karena karakteristik tanahnya 
yang mampu mengadsorpsi kontaminan, ketersediaan unsur hara yang memadai, benih kacang hijaunya bermutu tinggi, dan sifat hiperakumulator yang dimilikinya sehingga lebih toleran.

Pemanfaatan serbuk gergaji dalam pembuatan kompos telah dilakukan dalam penelitian sebelumnya. Waktu tercepat pengomposan sejalan dengan teori yaitu 14 hari dengan komposisi (1:1) ada keseimbangan antara jumlah sampah dapur dan serbuk gergaji. Apabila pengomposan dilakukan tanpa penambahan serbuk gergaji, waktu yang diperlukan > 18 hari dengan kondisi kompos yang masih basah dan berair. $^{25}$

\section{SIMPULAN}

Nilai Germination Index pada tanah tercemar Chrom $>80 \%$. Kondisi ini dipengaruhi karakteristik tanah yang mampu mengadsorpsi kontaminan dan karakteristik vigor benih kacang hijau yakni kuat tumbuh pada tanah yang tidak ideal. Nilai Germination Index pada tanah dengan variasi kompos $<80 \%$. Kondisi ini dipengaruhi $\mathrm{pH}$, semakin besar nilai $\mathrm{pH}$ diikuti dengan penurunan panjang akar kecambah. sehingga memengaruhi nilai Germination Index kompos menjadi lebih rendah dibandingkan dengan kecambah pada media tanah tercemar. Kondisi tanah yang tinggi alkalinitasnya setelah pemberian kompos, dapat ditambahkan kapur untuk menjaga $\mathrm{pH}$ netral sehingga biji-bijian bisa bisa tumbuh maksimal.

\section{UCAPAN TERIMA KASIH}

Penulis mengucapkan terima kasih kepada Poltekkes Kemenkes Bandung yang sudah memberikan dukungan dana penelitian ini.

\section{DAFTAR PUSTAKA}

1 Sh.M.Selim,Mona,S.Zayed,Houssam

M.Atta.Evaluation of Phtotoxicity of Compost During Composting Process.Nature and Science.2012;10(2)

2 Radovich T, Hue N, Pant A. Compost Quality. Western SARE. 2011 December.

3 Luo Y, Liang J, Zeng G, Chen M, Mo D et all. Seed Germination Test for Toxicity Evaluation of Compost. China. Elsevier. 2007.

4 Barrae MT, Paradelo R. Compost Quality Indicator.Global Science Books.2011.

5 Buttler,T.A,L.J.Sikora:P.M.Steinhilber and L.W.Douglas. Compost Age and Sample Storage Effects on Maturity Indicators of Biosolids Compost. Journal Environmental Quality. 2001. https://doi.org/10.2134/jeq2001.2141

6 BaumgartenA,Spiegel H. Phytotoxicity Agency for Health and Food Safety.2004.

7 A.K.Pendias and H. Pendias. Trace Elements in Soils and Plants. CRC Press. 2001.

8 Brinton WF.Compost Quality Standards and Guidelines.Woods and Research Laboratory. 2000 .
9 Amin H, Ahmed Arain B, Amin F, and Ali Srhio M. Phytotoxicity of Chromium on Germination, Growth and Biochemical Attributes of Hibiscus esculentus L. American Journal of Plant Sciences. 2013. https://doi.org/10.4236/ajps.2013.412302

10 Gapinathan $M$ and Thirusmurthy M. Evaluation of Phytotoxicity of Compost from Organic Fraction of Municipal Solid Waste and Paper and Pulp Mill Sludge. Environmental Research, Engineering and Management. 2102.

11 AsgharipourMR,SirousmehrAR.Comparison of Three Techniques for Estimating Phytotoxicity in Municipal Solid Waste Compost.Scholars Research Library.2012.

12 Ancuta D,Renata S,Carmen B.Seed Germination and Seeding Growth of Tomato as Affected by Different Types of Compost Water Extracts.Romania:Journal of Horticulture,Forestry and Biotechnology. 2013; vol 17(1):155-60.

13 Notodarmojo S. Pencemaran Tanah dan Air Tanah.Penerbit ITB, Bandung. 2005.

14 Rezvai, M and Zaefarian, F. Effect of Some Environmental Factors on Seed Germination of Eryngium caeruleum M.Bieb Polpulations. Acta Botanica Brasilica. 2017. https://doi.org/10.1590/0102-33062017abb0001

15 McCauley A, Jones C, and Olson-Rutz K. Soil pH and Organic. Module No.8. 2017 March.

16 Andre WG, Van der Wurff, JacquesG,Fuchs,Michael Raviv and $\mathbf{J}$ Termorshulzer.Handbook for Composting and Compost Use in Organic Horticulture.Bio Greenhous. 2020.

17 Moeljani,IR.Makhziah. Teknologi Benih True Shallot Seed :Gosyen Publishing. 2018.

18 Sadjad,S. Dari Benih Kepada Benih. PT.Gramedia Widiasarana Indonesia, Jakarta. 1993.

19 AJM Baker and PL Walker.Physiological Respons of Plants to Heavy Metals and The Quantification of Tolerance and Toxicity. Chemical Speciation and Bioavailability.2015.

20 Hidayah N. Fitoremediasi dan Potensi Tumbuhan Hiperakumulator. Hayati. Maret 2005, hal35-40. https://doi.org/10.1016/S19783019(16)30321-7

21 Menon,P. Joshi,N. Joshi,A. Respnse to Cadmium Sterss in Vigna radiata L., Trigonella foenumgraceum L., Oryza sativa L. and Pennisetum glaucum L: International Journal Biossays. 2019.

22 Joshi,N. Menon,P.Joshi,A. Effect of Chromium on Germination in Some Crops of India: Jorurnal Agricultural Science Botany.2019. https://doi.org/10.35841/2591-7897.3.1.1-5

23 Ashraf R, Ali TA.Effect of Heavy Metalson Soil Microbial Community and Mung Beans Seed 
Germination.Department of Microbiology. 25 Pujiono, Mulyati SS, Prijanto TB. Compost 2007; vol 39(2):629-36.

Quality Analysis of Various Variations in Green

24 Hohenheim S,Zaytseva O.Analysis of Phytotoxicity and Plant Growth Stimulation by Multi Walled Carbon

Nanotubes.Dissertation.Faculty of Agricultureal Sciences. 2016. 